REVIEW ARTICLE

PRACA POGLĄDOWA

\title{
THE RIGHT TO CLONE: SOME ASPECTS OF THE CONTEMPORARY DISCOURSE
}

DOI: 10.36740/WLek202003137

\author{
Anatoliy M. Potapchuk, Tereziia P. Popovych, Yevhen Ya. Kostenko, Yana 0. Baryska, Vasyl V. Levkulych \\ STATE UNIVERSITY «UZHHOROD NATIONAL UNIVERSITY», UZHHOROD, UKRAINE
}

\begin{abstract}
The aim: The paper aims to analyze some aspects of the contemporary discourse which concern the determination of the content and specificity of the right to clone. It also outlines the main trends in the development of legal regulation of cloning within international and national law and order.

Materials and methods: Methodologically, this work is based on the system of methods, scientific approaches, techniques and principles with the help of which the realization of the research aim is carried out. There have been applied universal, general scientific and special legal methods.

Conclusions: Regarding the findings of the study it is necessary to note the following. First, if there is a shared negative vision of the feasibility of reproductive cloning in general, which is enshrined in international and national legislation, the need for therapeutic cloning remains an unresolved issue. Secondly, medicine advances and accordingly sees new perspectives and innovative developments in the field of therapeutic activity, in particular, related to the results of therapeutic cloning, which can help in the fight against incurable diseases. Hence, there is the necessity of further research aimed at the improvement of the existing mechanisms for implementing therapeutic cloning, and determining its limits and procedural aspects.
\end{abstract}

KEY WORDS: human rights of the fourth generation; the right to clone; therapeutic cloning; reproductive cloning

Wiad Lek. 2020;73(3):597-602

\section{INTRODUCTION}

The 21st century was marked by outstanding advancement in the latest technologies and technological process. Due to the influence of this factor, almost all spheres of human life are modified. Obviously, the legal sphere is not an exception; in particular, the evidence of this, among other things, is the emergence of fundamentally new human rights, which in scientific doctrine, are commonly called fourth-generation rights.

Fourth-generation human rights, including those in the field of health care, are peculiar owing to the fact that they reflect the dynamics of social life and take into account the existing needs of society, creating new opportunities for the realization of human needs that undergo changes over time. However, despite the undoubtedly positive role of such development, these rights remain ambiguous and rather contradictory, sometimes coming into conflict with the shaped perceptions of society about certain norms of behavior, as well as with religious postulates.

The above-mentioned proves that the chosen topic is of vital interest for researchers. However, notwithstanding the considerable number of recent publications in this area, there still remain a number of challenging issues and controversial statements, especially regarding the determination of the content and perception of the right to clone.

\section{THE AIM}

The aim of the work is, therefore, to study and analyze some aspects of the contemporary discourse which reflect the current state of understanding and perceiving the appropriateness of the right to clone, characteristics of its nature, as well as to outline the main trends in the development of legal regulation of the sphere of cloning within international and national law and order.

\section{MATERIALS AND METHODS}

The methodological basis of this work includes a system of methods, scientific approaches, techniques and principles by means of which the research aim is realized. There have been applied universal, general scientific and special legal methods. Thus, in particular, the methods of analysis, synthesis, induction and deduction made it possible to generalize the obtained knowledge which became the basis of scientific exploration. In addition, due to the usage of the comparative method there have been compared the different points of view presented in the paper, and light has been shed on the specificity of the normative regulation of the investigated issues in certain countries.

\section{REVIEW AND DISCUSSION}

First of all, it should be stressed that human rights of the fourth generation in the field of health care are still called somatic, id est, those that are manifested in each person's possibilities to have control over their own bodies. It is believed that one of the first scholars who singled out a separate groupu of somatic rights to is V. I. Kruss. Analyzing V. I. Kruss's works, researchers underscore that somatic rights are difficult to fit 
into the existing classifications of human rights, since these rights are aimed at protecting bodily and spiritual integrity; at the same time these rights include an individual's ability to put forward certain personalized requirements to society. However, scholars argue that the nucleus of somatic rights is the right to life and human dignity, freedom of conscience, the right to liberty and personal security, which are fundamental to personal rights [1, p. 24].

As a rule, fourth-generation human rights in health care include the following: cloning; euthanasia; the use of assisted reproductive technologies (artificial insemination, surrogacy); transplantation; gender change; gay marriage and the like.

In the context of our study, the focus is on one of the most controversial rights of the fourth-generation concept in the field of health care, that is, the right to clone. Usually, when it comes to cloning we mean the creation of new living organisms, including humans, in artificial laboratory conditions.

Cloning can be defined as a system of methods used to obtain clones. The term "clone», which etymologically derives from the Greek word «klon» (a branch, sprout, shoot) was introduced in science by the English biologist John Burdon Sanderson Haldane in 1963. In the light of molecular biology it is a system of methods and techniques used for obtaining the cloned DNA or obtaining the genetically identical material in large quantities. There should be distinguished the cloning of genes, organisms, molecular cloning, etc. When cloning genes, individual genes of a cell are isolated and repeatedly copied. This technology can be used to produce a large amount of protein encoded by this gene. This is valuable for pharmacy, because it allows to artificially create protein which is necessary for the body if its natural synthesis is abnormal. In molecular cloning, DNA molecules are reproduced as part of a vector which is a plasmid or phage (DNA cloning).

Cloning of multicellular organisms is the process of transplanting the donor nucleus into the recipient cell, activating this hybrid unless it gets divided, of its development outside the body, and transplanting it into the uterus for further development. It can be embryonic and somatic. In embryonic cloning, the donors of the nuclei are cells of morulas or blastocysts, and in somatic cloning - somatic cells. In comparison with embryonic cloning, somatic cloning is a more recent development [2].

Human cloning is often characterized as the process of making a genetically identical copy of a human. The term is generally used to refer to artificial human cloning, which is the reproduction of human cells and tissues. This does not refer to natural conception (identical twins) [3]. Cloning a human requires the following: 1 ) a female ova from which its own nucleus is removed; 2 ) the donor cell to be cloned. The nucleus of this cell is transplanted into the ova; 3 ) the embryo obtained in this way is transferred into the uterus of the surrogate mother, that is, the woman who has agreed to go through with this pregnancy. A human, born in this way, is a clone. This human inherits entirely the genetic code of a donor (genotype).
However, it should be noted that viewing cloning in this narrow-minded way, from our perspective, much of its content, related to the cloning of human organs and tissues, is lost; the talk is about therapeutic cloning. Reproductive cloning presupposes the creation of a new organism under laboratory conditions wheras therapeutic cloning («cellular reproduction») is the same as reproductive cloning but with an embryonic growth term of up to fourteen days; during the first fourteen days embryonic cells are being formed, further they are able to transform into specific tissue cells of individual organs - a heart, kidneys, a liver, a pancreas, teeth, etc. which are used in medicine for the treatment of many diseases. Such cells of future organs are called «embryonic stem cells» [4, p. 188-189].

Hence, depending on the set goals, there are distinguished two types of cloning. The first type, as the reproduction method, is aimed at reproducing a human or other creatures (reproductive cloning) whereas the second type, cloning for medical purposes (therapeutic cloning), is used for regenerating organs of the same person or producing medicines. The latter does not aim to fully reproduce living beings and methodologically proceeds without the use of a donor uterus.

At the same time, a number of scholars believe that, from a legal point of view, human cloning conflicts with the most important rights of the person, i. e. the right to human dignity and the right to integrity of the person. There is no need to talk about those legal issues that will be caused by the appearance of a human clone. The first issue which arises is related to the fact whether a human clone will be a legal personality, and if so, will his legal personality coincide with the legal personality of the original. An immense legal problem will be the regulation of relationship between the original person and his clone, at least in terms of identification of the person, succession, family relations, etc. [5].

Today, most countries in one form or another have banned cloning. In particular, this applies to Belgium, the United Kingdom, Denmark, Spain, Italy, the Netherlands, Germany, Slovakia, France, Switzerland, Sweden, Japan, which have legislated this issue. Ukraine has also followed this way by adopting the Law «On the Prohibition of $\mathrm{Hu}$ man Reproductive Cloning» in 2004 [6].

Regarding the legislative regulation of this issue in other countries, in Australia and Italy, laws to ban cloning were passed in 2001. The South Korean Parliament, under the influence of the public, passed the law in 1998 which allows cloning a human cell only to fight cancer and other diseases. It should be stressed that most countries signed the Additional Protocol to the Convention for the Protection of Human Rights and Dignity of the Human Being with regard to the Application of Biology and Medicine, on the Prohibition of Cloning a Human Being. They have imposed criminal liability for experimenting in this field: up to 20 years of imprisonment in France, in Germany - 5 years, in Japan - 10 years [7, p. 49].

These days the practice of criminalization of human cloning is actively being in the world. In particular, such 
norms are part of the criminal codes of Spain (1995), El Salvador (1997), Colombia (2000), Estonia (2001), Mexico (2002), Moldova (2001), Slovakia (2003). The Criminal Code of France was supplemented by the provision which establishes liability for cloning under the Bioethics Act dated August 6, 2004 [8, p. 151]

Of interest is the situation in Germany, where for a long time there were regulations that severely restricted research dealing with human embryonic stem cells. In particular, its Law "On the Protection of Embryos in Relation to the Import and Use of Human Embryonic Stem Cells» of June 2002 generally prohibited importing and receiving embryonic stem cells (hereinafter referred to as ESCs). However, in terms of import limitations there were introduced some exceptions, in particular, for accomplishing «overarching scientific purposes»: ESC lines could only be imported prpvided they had been obtained (isolated) from embryo-fetal materials only (dead embryos) by 1 January 2002. Nevertheless, on April 11, 2008, the German Bundestag decided to «soften» the time limit set in the previous version, allowing German researchers to import ESCs that had been isolated by May 1, 2007, which certainly expanded their capabilities. Anyway, cloning of human embryos in Germany is forbidden, in particular, in $\$ 6$ of the Law of the Federal Republic of Germany «On the Protection of Embryos» which has been in force since 1991. It says: « The one who with his actions creates an embryo that has the same genetic information as another embryo, a fetus, a person alive or dead, shall be punished by a fine or imprisonment for a term up to five years " $[9$, p. 89].

Italy, Denmark, France and the Netherlands have similar legislation. In Switzerland, the prohibition of cloning is carried out at the constitutional level, in particular, in section «a» of Part 2 of Art. 119 of the 1999 Constitution. It states that all types of cloning and interference with the hereditary material of human gametes and embryos are not allowed [10]. In 2003, the House of Representatives of the United States Congress passed the law that viewed cloning, whose purpose includes reproduction, medical research and treatment, as criminal and could result in imprisonment for a period of 10 years and a fine of $\$ 1$ million. However, in January 2009, criminal liability for therapeutic cloning was abolished [8, p. 151-152].

In 1990 in Great Britain The Human Fertilization and Embriology Act was adopted; according to it, « the fusion of cell nuclei of the human embryo with nuclei which were isolated from cells of another person's tissue, of an embryo or foetus, is forbidden ». It is based on the Governmental Commission's report on Ethical Issues in Embryology. The law prohibited human cloning, «if cells removed from embryonic tissues were used for this purpose». In cases when the donor was an adult organism, this prohibition did not apply.

Already in 2000, the British Parliament cancelled the legal restrictions on cloning. In December of that year, the House of Commons approved a bill that allows the use of cloned human embryos for scientific purposes. And in
January 2001, 212 members of the House of Lords voted in favor of it (92 members voted against it). However, in June, the British Royal Society advocated the prohibition of human cloning, except for the cloning of human cells for therapeutic purposes [7, p. 49].

In this context, it is worth noting that in some countries (Australia, Belgium, Italy, Colombia, Mexico, New Zealand, the Netherlands, Romania, France, Sweden, etc.), despite the existing ban on reproductive cloning therapeutic cloning is allowed.

In addition to the prohibition at the national level in some countries, prohibition norms also act at the level of the international community. For example, in 1997 the Universal Declaration on the Human Genome and $\mathrm{Hu}$ man Rights was adopted, which in Art. 11 enshrined the impossibility of cloning as a practice which is contrary to human dignity [11].

In 1997, there was adopted the Convention for the Protection of Human Rights and Dignity of the Human Being with regard to the application of Biology and Medicine: the Convention on Human Rights and Biomedicine. According to this document, any interventions undertaken to modify the human genome can be carried out only for prophylactic, diagnostic or therapeutic purposes, and only if they are not aimed at making any alteration in the genome of the offspring. However, it is stated that the cultivation of human embryos for research purposes is prohibited [12].

Therefore, in 1998, in the light of scientific advances in the field of mammalian cloning and fears that human cloning could become a viable opportunity through the development of bioethics, medicine and new technologies, a number of European countries signed an Additional Protocol to the Convention on the Protection of Human Rights and Human Dignity with regard to the Application of Biology and Medicine, on the Prohibition of Cloning of Human Beings. This document prohibits any interference with the purpose of creating a human being that is genetically identical to another human being [13].

It must be emphasized that in 2005, the UN General Assembly adopted the Declaration on Human Cloning, stating that cloning for the purpose of reproducing a human being is contrary to human dignity and should not be allowed by UN member states, which are to take steps to ban human cloning as quickly as possible at the national level and take all possible measures to prevent it [14].

At the European Union level, the issue of cloning is raised in the Charter of Fundamental Rights of the European Union dated December 7, 2000. In this act, cloning is discussed in the context of Art. 3 which concerns the right to personal inviolability which, according to the authors of the document, is protected, in particular by prohibiting reproductive cloning [15].

Admittedly, the European Court of Human Rights (ECHR) considers it inadmissible to create embryos artificially for the purpose of their further use for scientific purposes [16]. Particularly, this is observed in the ECHR's case of «Parrillo versus Italy», which forbade the com- 
plainant to donate his embryos obtained by fertilization for scientific purposes, with the emphasis that embryos cannot be objects of property which can be freely disposed of by the person [17].

The European Court of Justice in its decision related to "Oliver Brüstle v. Greenpeace » case dated 2011, also referred to the prohibition of patenting the results of the research that had been obtained by destroying a human embryo or using it as the source material [18, p. 139].

It should be underscored that the content of the documents analyzed above manifests and proves that the prohibition is imposed only on reproductive cloning, since therapeutic cloning does not include any characteristics indicated in these acts. That is why the issue of feasibility of the latter remains open. The urgency of its solving is reinforced by the fact that, at the national level, in some countries, as noted above, therapeutic cloning is permitted.

If we generalize the positions of proponents of the prohibition of cloning, they suggest the following arguments: 1) cloning violates human dignity, reduces human life to the level of «biological material»; 2) it separates the sphere of childbearing from the true human context of the matrimonial act; 3 ) demonstrates the lack of respect for human embryos that will be destroyed so that reproduction of this type can occur successfully (in the case with cloning Dolly the sheep there were made 277 attempts, 8 of them were successful and brought to the embryo develepment, as a result, only one sheep was born; 4) cloning is a radical manipulation of the human reproduction, in which personal relationships between parents and children are broken and this can lead to the disappearance of the concept of family and family relationships; 5) cloning is inadmissible taking into account the cloned person's dignity. Everyone has the right to his own uniqueness. The human body and genotype are also an integral part of dignity and uniqueness, whereas a cloned human being is always a "copy» of someone else, which can lead to the loss of human identity and to the feeling of inferiority; 6) cloning creates the danger of social manipulation in the light of eugenics, the choice of «genetically better» people; 7) producing «clones» of living persons solely as a source for organ transplantation makes one view the person merely as an object of use, which is completely unacceptable from the point of view of Christian personalism $[19$, p. 8$]$.

However, such a perception of the right to clone is a rather narrow-minded approach, which contradicts the very essence of science on the one hand, and on the other hand, it comes to assessing the nature of reproductive cloning. In general, accepting the researchers' vision of this type of cloning and agreeing to it, we consider it necessary to dwell upon possible useful results of the approbation of therapeutic cloning. First of all, ther should be mentioned the arguments of researchers who advocate for the right to clone in general. As a matter of fact, they defend the personal right of everyone to reproduce, to continue the bloodline, which is an integral part of the person's autonomy (along with such rights as the right to contraception, in vitro fertilization, artificial insemination, etc.). The technology of somatic cell nucleus transfer (cloning), in their opinion, is just one of the varieties of the production mechanism. They are convinced that the ban on cloning contradicts the principle of freedom of scientific research. The laureates of the International Academy of Humanism, the moral and ethical issues generated by cloning are not bigger than those people have already faced (nuclear energy, recombinant DNA or computer modeling) - they are just new [20, p. 73].

As for therapeutic cloning, when it comes to cloning of cells and tissues of living organisms with the use of modern molecular-genetic methods, we believe that humanity receives and will receive the benefits of the application of such technologies. These benefits in no way violate or diminish human dignity, because the outcomes of these activities can improve the functioning of science, medicine, agriculture and more. Particularly significant is the aspect related to therapeutic activity, since it is impossible to deny the importance of therapeutic cloning for overcoming serious diseases such as cancer, diabetes, Parkinson's disease, Alzheimer's disease and others.

The fact which is worth mentioning is that this year British researchers have succeeded in creating artificial nerve cells that can be used to treat humans in the future. These are tiny chips made of silicon, to which the researchers managed to transfer the electrical properties of brain cells. They reproduced two types of neurons: nerve cells from the hippocampus - the part of the brain responsible for memory and thee cells involved in regulating respiration. The researchers stress that they want to involve artificial nerve cells in the treatment of diseases which cause the degeneration and death of neurons, for example, Alzheimer's disease or cardiac failure.

The researchers from Israel managed to print a real heart on a 3D printer. Human fat cells were used as the material for producing a heart; they were transformed into stem cells of the cardiovascular muscle and connected with connective tissue. After conducting the research, the heart can be used in transplantology. The developers think that in the next few years there will be an opportunity to create any organ for transplantation, taking into account the peculiarities of each patient [21].

Thus, it is obvious that scholars are trying to develop mechanisms for the «restoration» or «replacement» of human organs and tissues in order to preserve and extend human lifespan, as well as to use the biological materials, obtained in this way, as therapeutic agents and medicines. This mechanism, which is an alternative to the current practice of organ and tissue transplantation from a donor (a living or dead person) to another person (a recipient), makes it possible to completely eliminate the criminal "component» and to significantly increase the likelihood of engraftment of organ and tissue obtained as a result of self-transplantation. Currently, there are positive results of therapeutic cloning of cells taken from a patient who requires the implantation of a particular organ or tissue, as well as the use of the technology of obtaining stem 
cells from umbilical cord blood. Experimental cloning of organs or tissues for self-transplantation is also carried out, during which a cell, taken from a particular person, allows growing an organ or tissue for this person. In experts' opinion, such transplantation will never lead to incompatibility, so it will not require the use of special drugs that prevent the rejection of transplanted organs or tissues whose DNA is identical, and will not cause any side effects [22].

Speaking about the cloning situation in Ukraine, as it has been previously stated, in 2004 the Law «On Prohibition of Human Reproductive Cloning» was approved. However, therapeutic cloning remains unaddressed. According to such experts in the field of medical law as Prof. S. H. Stetsenko, Prof. V. Yu. Stetsenko and Assist. Prof. I. Ya. Seniuta, the necessity of introducing therapeutic cloning in Ukraine is indisputable, but they advocate the expediency of introducing therapeutic cloning on the territory of Ukraine gradually (in stages), that is, initially for a certain period (determined not by time frames, but by the readiness of society and the state for this process). This will enable to prevent abuse, scientific failures, violation of ethical and moral principles. We shall be able to talk about the possibility and expediency of permitting therapeutic cloning in Ukraine only with time, when a proper legal framework has been established and all the necessary authorities have been created (for example, the ethical and legal committee consisting of independent experts) to sustain this process through the development and implementation of governmental programs concerning the study of this issue, analysis of scientific, practical , experimental experience of foreign countries, taking into account the opinions of researchers who work in different spheres, as well as the public opinion, [10].

\section{CONCLUSIONS}

Thus, the issues of the fourth generation in today's realities are becoming more global and require thorough doctrinal approaches to the study and analysis of their nature in general and their separate components in particular. As for the right to clone, which became the focus of this scientific exploration, we consider it necessary to highlight the following. First, talking about the feasibility of reproductive cloning, generally, there is the common opinion, which is enshrined in national and international legal acts, whereas when it comes to therapeutic cloning, the opinion on its need is either largely defended or unclear (as, for instance, in Ukraine).

Second, there is no denying the fact that medicine advances and accordingly sees new perspectives and new developments in the field of therapeutic activity, in particular, in connection with the results of therapeutic cloning, which can help to combat incurable diseases. It can be anticipated that the development of therapeutic cloning is inevitable and, definitely, needed to improve the living conditions of present and future generations. That is why the research aimed at improving the existing mechanisms for conducting therapeutic cloning, determining its boundaries and procedural aspects should be continued and deepened. This, in turn, will help to create and provide the proper conditions for the realization of individuals' right to clone if there are needs related to threats to their lives and health.

\section{REFERENCES}

1. Goncharov I.V.Somaticheskie prava:voprosyi yuridicheskogo priznaniya i praktika realizatsii [Somatic Rights: Issues of Legal Recognition and Implementation Practice]. Scholarly Writings of the Academy of Management of the Ministry of Internal Affairs of Russia. 2018; 2 (46): 23-25. (in Russian).

2. Tymchuk N. F. Klonuvannia [Cloning]. Pharmaceutical Encyclopedia. doi: https://www.pharmencyclopedia.com.ua/article/3585/klonuvannya. (in Ukrainian).

3. Martinez B. Scientists clone monkeys using technique that created Dolly the sheep. F0X 61 (en-US). January 25, 2018. doi: https://fox61. com/2018/01/25/watch-scientists-clone-monkeys-using-techniquethat-created-dolly-the-sheep/.

4. Mikhnova Ye. H. Mizhnarodno-pravovi aspekty rehuliuvannia klonuvannia [International-Legal Aspects of Cloning Regulation]. Topical Issues of International Relations. 2009; 83 (Part II): 188-196. (in Ukrainian).

5. Lysokin A. Pravovi aspekty klonuvannia liudyny [Legal Aspects of Human Cloning]. The All-Ukrainian General Political Educational Weekly Personnel Plus. May 2012; 21 (478). doi: http://www.personal-plus. net/478/9234.html. (in Ukrainian).

6. Pro zaboronu reproduktyvnoho klonuvannia liudyny: Zakon Ukrainy vid 14.12.2004 r. № 2231-IV [0n the Prohibition of Human Reproductive Cloning: Law of Ukraine of December 14, 2004 No. 2231-IV]. Bulletin of the Supreme Council. 2005; 5: 111. (in Ukrainian).

7. Korotkyi T. Pravoviaspekty klonuvannia liudyny [Legal Aspects of Human Cloning]. Bulletin of the National Academy of Sciences of Ukraine. 2002; No. 3: 46-52. (in Ukrainian).

8. Khimchenko S. Do pytannia kryminalizatsii klonuvannia liudyny [0n the Issue of Criminalization of Human Cloning]. National Law Journal: Theory and Practice. July 2017; 4: 151-153. (in Ukrainian).

9. Kvit N. M. Pravovi mezhi stvorennia ta vykorystannia liudskykh embrioniv: porivniannia nimetskoho ta ukrainskoho zakonodavstva [Legal Restrictions of Creation and Use of Human Embryos: The Comparison of German and Ukrainian Legislations]. ComparativeAnalytical Law. 2019; 3: 87-92. (in Ukrainian).

10. Stetsenko S. H., Stetsenko V. Yu., Seniuta I. Ya. Medychne pravo Ukrainy [Medical Law of Ukraine]. A Textbook / ed. by Doc. of Law, Professor S. H. Stetsenko. K .: The All-Ukrainian Association of Publishers «Legal Unity»; 2008, 507 p. doi: https://medcoledg.ucoz.ru/Likspr/pravno/ medpravoua2008.pdf. (in Ukrainian).

11. Zahalna deklaratsiia pro henom liudyny ta prava liudyny vid 11 lystopada 1997 r. [Universal Declaration of the Human Genome and Human Rights of November 11, 1997]. doi: https://zakon.rada.gov.ua/laws/ show/995_575.

12. Konventsiia pro zakhyst prav i hidnosti liudyny shchodo zastosuvannia biolohii ta medytsyny: Konventsiia pro prava liudyny ta biomedytsynu [The Convention for the Protection of Human Rights and Dignity with regard the Application of Biology and Medicine: Convention on Human Rights and Biomedicine]. Oviedo, April 4, 1997. doi: https://zakon.rada. gov.ua/laws/show/994_334.]. (in Ukrainian). 
13. Dodatkovyi protokol do Konventsii pro zakhyst prav i hidnosti liudyny shchodo zastosuvannia dosiahnen biolohii ta medytsyny, stosovno zaborony klonuvannia liudskykh istot. Paryzh, 12 sichnia 1998 r. [The Additional Protocol to the Convention on the Protection of Human Rights and Dignity of Human Beings with the regard to the Application of Biology and Medicine, on the Prohibition of Cloning Human Beings. Paris, January 12, 1998]. doi: https://zakon.rada.gov.ua/laws/ show/994_526. (in Ukrainian).

14. Deklaratsiia Orhanizatsii Obiednanykh Natsii pro klonuvannia liudyny: pryiniata rezoliutsiieiu Heneralnoi asamblei 59/280 vid 08.03. $2005 \mathrm{r}$. [The United Nations Declaration on Human Cloning: adopted by the General Assembly's Resolution 59/280 of 08.03. 2005]. doi: https:// zakon.rada.gov.ua/laws/show/995_d57. (in Ukrainian).

15. Khartiia osnovnykh prav Yevropeiskoho Soiuzu. Nitstsa, 07.12.2000 r. [The Charter of Fundamental Rights of the European Union. Nice, December 7, 2000]. doi: https://zakon.rada.gov.ua/laws/ show/994_524. (in Ukrainian).

16. TrikozE.N., Gulyaeva E. E. Pozitsii ESPCh po nekotoryim voprosam bioetiki i geneticheskih dannyih. Advances in Law Studies. 2018; Tom 6; 4 [The Positions of the ECHR on Some Issues of Bioethics and Genetic Data]. Advances in Law Studies. 2018; Volume 6; 4. doi: https://naukaru.ru/ ru/nauka/article/24159/view. (in Russian).

17. Case of Parrillo v. Italy: application № 46470/11. European Court of Human Rights. Strasbourg, 27.08.2015. doi: https://hudoc.echr.coe. int/eng\#\{\%22itemid\%22:[\%22001-157263\%22].

18. Tkachuk V. V. Posledstviya resheniya Suda ES po delu «Oliver Bryustle protiv Greenpeace» dlya uregulirovaniya genomnyih issledovaniy v Evropeyskom Soyuze [The Consequences of the Decision of the EU Court in the case of «Oliver Brewstle v. Greenpeace» for regulating genomic research in the European Union]. Bulletin of the University named after 0. E. Kutafin (Moscow State Academy of Law named after 0. E. Kutafin). 2019 4: 138-145. (in Russian).

19. Antoniuk 0. R. Etyko-pravovi problemy klonuvannia liudskoho orhanizmu [Ethical and Legal Issues of Cloning A Human Organism]. Medical Law of Ukraine: The Legal Status of Patients in Ukraine and its Regulatory Framework (genesis, development, problems and prospects for improvement): The Proceedings of the II All-Ukrainian Scientific-Practical Conference (Lviv, April 17-18, 2008). Lviv; 2008: pp. 7-11. (in Ukrainian).
20. Trynova Ya. Klonuvannia liudyny - odna iz suchasnykh kryminalnopravovykh problem. Yurydychna Ukraina [Human Cloning as One of the Modern Criminal-Legal Issues]. Legal Ukraine. 2014; 1: 72-79. (in Ukrainian).

\section{ORCID and contributionship:}

Anatoliy M. Potapchuk - 0000-0001-9857-1407 A, D, F

Tereziia P. Popovych - 0000-0002-8333-3921 A, D, F.

Yevhen Ya. Kostenko. ORCID - 0000-0002-3997-2371 A, E, F

Yana O. Baryska - 0000-0001-5382-7974 B, C, D

Vasyl V. Levkulych - 0000-0001-9534-8971 B, C, D

\section{Conflict of interest:}

The Authors declare no conflict of interest.

\section{CORRESPONDING AUTHOR}

\section{Tereziia P. Popovych}

State University «Uzhhorod National University», Sq. Folk, 3, 88000, Uzhhorod, Ukraine

tel: +380956261986

e-mail:buts_tereza@ukr.net

Received: 17.01 .2020

Accepted: 05.03.2020

A - Work concept and design, B - Data collection and analysis, C - Responsibility for statistical analysis, $\mathbf{D}$-Writing the article, $\mathbf{E}$-Critical review, $\mathbf{F}$ - Final approval of the article 